\title{
Pengaruh Penggunaan Internet Sebagai Sumber Belajar Terhadap Motivasi Belajar Siswa SMTK Long Bia Kecamatan Peso Kabupaten Bulungan Provinsi Kalimantan Utara
}

\author{
Novel Batang
}

\begin{abstract}
Abstrak
Adapun tujuan yang hendak dicapai dalam penulisan skripsi ini adalah untuk mengetahui pengaruh penggunaan Internet sebagai sumber belajar terhadap motivasi belajar siswa SMTK Long Bia Kecamatan Peso Kabupaten Bulungan Kalimantan Utara. Berdasarkan hasil penelitian maka penulis menyimpukan bahwa: Pertama, hasil kuisioner dalam penggunaan internet dari 36 siswa diketahui tentang tingkat penggunaan internet sebagai sumber belajar sebagai berikut: 8 siswa $(22,22 \%)$ mengatakan bahwa pemanfaatan internet sebagai sumber belajar dalam kriteria sangat baik, 18 siswa $(50,00 \%)$ mengatakan bahwa penggunaan internet sebagai sumber belajar dalam kriteria baik, 10 siswa (27,78\%) mengatakan bahwa penggunaan internet sebagai sumber belajar dalam kriteria cukup baik, 0 siswa $(0,00 \%)$ mengatakan bahwa penggunaan internet sebagai sumber belajar dalam kriteria tidak baik dan sangat tidak baik. Dari hasil tersebut dapat dijelaskan bahwa secaraumum penggunaan internet sebagai sumber belajar siswa kelas X-XII SMTK Long Bia tahun ajaran 2016/2017 sudah baik. Kedua, penggunaan internet sebagai sumber belajar terhadap motivasi belajar siswa kelas X-XII SMTK Long Bia tahun ajaran 2016/2017ternyata ada pengaruh signifikan penggunaan internet sebagai sumber belajar terhadap motivasi belajar. Berdasarkan deskripsi terlihat bahwa paling banyak siswa menggunakan internet sebagai sumber belajar dalam kategori baik sebesar $(50,00 \%)$, sedangkan motivasi belajar dalam kategori baik sebesar $(63,89 \%)$. Dalam hal ini dapat disimpulkan bahwa semakin tinggi penggunaan internet sebagai sumber belajar, maka semakin tinggi pula motivasi belajar siswa.
\end{abstract}

Kata-kata Kunci: Pengaruh, Penggunaan, Internet, Sumber, Belajar, Motivasi, Peso, Bulungan 


\section{Pendahuluan}

\section{Latar Belakang Masalah}

UU RI No. 20 Tahun 2003 tentang Sistem Pendidikan Nasional, khususnya pasal 1 dinyatakan bahwa konsep pembelajaran adalah suatu interaksi antara peserta didik dengan pendidik dan sumber belajar pada suatu lingkungan belajar. Konsep mengenai pembelajaran di atas melahirkan suatu model pembelajaran yang dikenal dengan pembelajaran berbasis aneka sumber memungkinkan siswa belajar dari siapa, dari mana saja, tentang apa saja.

Pembelajaran berbasis aneka sumber memungkinkan terciptanya suatu situasi pembelajaran yang "hidup" dan menarik. Hal ini sejalan dengan tuntutan yang ada di dalam PP RI No. 19 Tahun 2005 tentang Standar Nasional Pendidikan. Di dalam peraturan ini dinyatakan bahwa, proses pembelajaran pada satuan pendidikan diselenggarakan secara interaktif, inspiratif, menyenangkan, menantang, memotivasi peserta didik untuk berpartisipasi aktif, serta memberikan ruang yang cukup bagi prakarsa, kreativitas, dan kemandirian sesuai dengan bakat, minat, dan perkembangan fisik serta psikologis peserta didik. Salah satu cara yang dapat dilakukan oleh satuan kelas adalah pemanfaatan Teknologi dan Komunikasi yang selanjutnya disingkat TIK dalam proses pembelajaran dalam hal ini penggunaan internet.

Diketahui, teknologi informasi berkembang pesat melebihi bidang lainnya. Faktor penentunya adalah globalisasi informasi, yaitu penyebaran akses dan produksi informasi keseluruh dunia. Informasi dapat diakses oleh siapa saja dan di mana saja. Perkembanga nlintas batas informasi adalah hal yang tercepat. Keadaan ini juga berpengaruh pada dunia pendidikan karena proses pendidikan pada dasarnya adalah perpindahan informasi terpilih yang tidak lagi terbatas antara murid dan guru bahkan juga harus mulai dibuka kesumber-sumber informasi yang lebih luas seperti buku dan pusat aktivitas dalam masyarakat luas, lokal, nasional, dan global.

Pesatnya perkembangan teknologi informasi ini membawa dampak bagi kehidupan manusia, terutama dunia pendidikan. Dampak positifnya terkait erat dengan peningkatan kualitas kehidupan. Informasi begitu mudah diperoleh baik lewat media massa, elektronik, maupun melalui jaringan teknologi internet. Menurut Ghufron dalam Parji (2011:102), terpajangnya bahan informasi lewat media massa, baik elektronik maupun cetak, berpengaruh sangat positif terhadap pembaca. Selain muatannya yang mungkin bermanfaat bagi pembaca, media informasi tersebut juga memberikan pajangan yang berdampak positif terhadap akuisisi bahasa para pembaca. ${ }^{1}$

Sebagaimana yang dikemukakan oleh Fazilah Idris diakui bahwa,"internet merupakan jaringan informasi, komunikasi, penyelidikan, dan berbagai sumber yang tidak terhingga banyaknya yang dapat digunakan untuk membantu siswa

${ }^{1}$ Ghulfron, diakses, 9 September 2016, http://lib.unnes.ac.id/19021/1/3101408030.pdf 
menghasilkan tesis, kerja proyek, dan sebagainya. Internet sebagai alat untuk mencapai informasi dalam skala global. Siswa kini dapat memperoleh informasi yang lebih daripada apa yang terdapat dalam buku teks dengan mencari dan mengakses semua website di seluruh dunia." 2

Internet sebagai sumber informasi yang sangat luas didukung dengan adanya lebih dari 30.000 konferensi elektronik online dan lebih dari 2500 jurnal elektronik online, menjadi alternatif yang sangat menarik untuk penyediaan sumber daya manusia yang dibutuhkan. Terdapat paling tidak 50 perguruan tinggi negeri dan lebih dari 1200 perguruan tinggi swasta belum terhitung sekolah tingkat menengah SLTP, SMA, SMK dan lain-lain yang mengakses jaringan internet. Iniberarti total pengguna internet seluruh Indonesia adalah satu juta pengguna, yang artinya $4 \%$ pengguna internet seluruh dunia berada di dunia pendidikan di Indonesia.

Menyadari potensi dan upaya internet sebagai wadah komunikasi dan interaksi elektronik yang menarik maka kementerian Pendidikan telah mengambil langkah untuk memperkenalkan internet kepada para pelajar dan pendidik. Maka seiring dengan meningkatnya peranan informasi dalam berbagai aktivitas kehidupan maupun teknologi, akses terhadap sumber dan jaringan informasi menjadi semakin penting bagi siapapun. Internet adalah jaringan informasi yang berkembang sangat pesat dan dapat dikatakan sebagai jaringan informasi terbesar di dunia pada saat ini. Kini internet digunakan oleh jutaan manusia dengan berbagai tujuan termasuk untuk tujuan pendidikan. Internet di bidang pendidikan sangat berguna dalam proses belajar mengajar di sekolah dimana para siswa dapat melengkapi ilmu pengetahuannya, sedangkan guru dapat mencari bahan ajar yang sesuai dan inovatif melalui internet. Murid dapat mencari apa saja di internet, mulai dari mata pelajaran hingga ilmu pengetahuan umum semuanya bisa dicari di internet. Sedang guru bisa mencari informasi yang dapat dijadikan bahan untuk mengajarkan materi kepada siswanya selain dari buku.

Penggunaan Internet sebagai media pendidikan dapat dianggap sebagai suatu hal yang sudah jamak digunakan di kalangan pelajar.Untuk itu sekolah-sekolah bisa menjadikan Internet sebagai sarana untuk belajar selain buku dan agar mampu menjadi solusi dalam mengatasi masalah yang selama ini terjadi, misalnya minimnya buku yang ada di perpustakaan, keterbatasan tenaga ahli, waktu belajar yang terbatas. Menyadari bahwa di Internet dapat ditemukan berbagai informasi apa saja, maka pemanfaatan Internet menjadi suatu kebutuhan. Dalam setiap aktifitas belajar mengajar, guru adalah seorang yang memberikan bimbingan kepada anak didiknya, dan juga seorang guru juga harus mempunyai profesionalitas yang tinggi terhadap keahliannya. Wasino mengatakan: "Selain itu guru juga harus mempunyai suatu keahlian dibidang teknologi Informasi terutama internet, karena pada zaman sekarang guru dituntut untuk bisa menggunakan Internet karena bisa menggali lebih

${ }^{2}$ Fazilah Idris,Jurnal Bahasa (Pembelajaran Bahasa), (Termuat dalam Makalah Internet dan Belajar Berkumpul 2010), 1. 
banyak lagi informasi selain yang ada di buku. Dalam hal ini, belajar berbasis aneka sumber bebas adalah suatu paradigma baru pada lapis pengalaman belajar." Sampai sekarang pengalaman belajar siswa masih memusat pada perang guru (teacher centered leraning), seolah-olah tanpa guru tidak terjadi proses pembelajaran. Dalam perspektif seperti itu,maka teknologi pendidikan sebagai salah satu disiplin terapan mempunyai peran yang sangat penting.Disiplin ilmu ini berorientasi pada bagaimana memecahkan masalah belajar dan pembelajaran dengan menggunakan berbagai sumber, baik yang telah tersedia maupun yang sengaja dikembangkan.

\section{Pokok Masalah}

Mengacu pada latar belakang masalah di atas, maka pokok masalah utama yang akan dibahas dalam penulisan skripsi ini adalah: Sejauh manakah pengaruh penggunaan Internet sebagai sumber belajar terhadap motivasi belajar siswa SMTK Long Bia Kecamatan Peso Kabupaten Bulungan Kalimantan Utara?

\section{Tujuan Penelitian}

Adapun tujuan yang hendak dicapai dalam penulisan skripsi ini adalah untuk mengetahui pengaruh penggunaan Internet sebagai sumber belajar terhadap motivasi belajar siswa SMTK Long Bia Kecamatan Peso Kabupaten Bulungan Kalimantan Utara.

\section{Manfaat Penelitian} berikut:

Hasil dari penulisan skripsi ini diharapkan akan memberikan manfaat sebagai

Pertama, manfaat Teoritis. Memperkaya kajian tentang peranan penggunaan internet sebagai sumber belajar dalam menunjang motivasi belajar siswa.

Kedua, manfaat Praktis. Memberikan informasi atau masukan bagi lembaga terkait dalam meningkatkan motivasi belajar siswa.

\section{Metode Penelitian}

Metode penelitian yang penulis gunakan di dalam penyusunan skripsi ini adalah penelitian kuantitatif dengan teknik pengumpulkan data melalui kajian pustaka untuk mengumpulkan data yang berkait dengan pembahasan. Penulis juga mengadakan observasi langsung di lapangan yaitu dengan cara membagikan angket (terbuka) yang disebarkan kepada siswa SMTK penggunaan Internet sebagai sumber belajar bagi para siswa. ${ }^{4}$

\section{Batasan Penelitian}

\footnotetext{
${ }^{3}$ Wasino, Dari Riset Hingga Tulisan Sejarah. (Semarang: UNNES Press, 2007), 3.

${ }^{4}$ Hengki Wijaya (ed.), Metodologi Penelitian Pendidikan Teologi (Makassar: Sekolah Tinggi Theologia Jaffray, 2016), 24,26.
} 
Penulisan skripsi ini memaparkan secara khusus tentang pengaruh penggunaan internet sebagai ruang lingkup peneliti terhadap motivasi belajar terhadap belajar siswa SMTK Long Bia.

\section{Kepustakaan}

Idris, Fazilah. Jurnal Bahasa (Pembelajaran Bahasa). Termuat dalam Makalah Internet dan Belajar Berkumpul, 2010.

Pandie, Mira Marleni, Ivan Th. J. Weismann. "Pengaruh Cyberbullying Di Media Sosial Terhadap Perilaku Reaktif Sebagai Pelaku Maupun Sebagai Korban Cyberbullying Pada Siswa Kristen SMP Nasional Makassar.” Jurnal Jaffray 14, no. 1 (2016). http://dx.doi.org/10.25278/jj71.v14i1.188

Wasino. Dari Riset Hingga Tulisan Sejarah. Semarang: UNNES Press, 2007.

Weismann, Ivan Th. J. "Analisis Pengaruh Gaya Kepemimpinan Dosen Terhadap Motivasi Belajar Mahasiswa Sekolah Tinggi Theologia Jaffray Makassar." Jurnal Jaffray 11, no. 1 (2013).

Wijaya, Hengki (ed.). Metodologi Penelitian Pendidikan Teologi. Makassar: Sekolah Tinggi Theologia Jaffray, 2016. 